\title{
Factors Affecting the Need to have Accounting Technical Competence, Professional Skills and Professional Values, Ethics, and Attitudes - The Case of Thailand
}

\author{
Naruanard Sarapaivanich*, Worraphan Trakarnsirinont, \\ Suvanna Laohavisudhi and Tanikan Viriyachinkarn
}

\begin{abstract}
Manuscript type: Research paper

Research aims: This study aims to examine the factors affecting accounting professionals' essential skills as specified by the International Education Standards (IESs).

Design/Methodology/Approach: The antecedent factors are drawn from Aldefer's (1969) theory of existence, relatedness and growth needs (ERG). A mixed method approach involving auditors, standard setters and faculty members is employed in this study.

Research findings: The results suggest that accounting professional skills are motivated by the growth and relatedness needs. The findings further reveal that the length of accounting training experience and the students' intention to work in accounting fields,
\end{abstract}

\footnotetext{
* Corresponding author: Naruanard Sarapaivanicha is Lecturer at the Department of Accounting, Faculty of Business Administration, Chiang Mai University, Thailand. Email: naruanard.s@cmu.ac.th, naruanard@gmail.com.

Worraphan Trakarnsirinonta is Lecturer at the Department of Accounting, Faculty of Business Administration, Chiang Mai University, Thailand. Email: worraphan.t@cmu.ac.th, ohobear20@ hotmail.com

Suvanna Laohavisudhi is Lecturer at the Department of Accounting, Faculty of Business Administration, Chiang Mai University, Thailand. Email: suvanna.1@cmu.ac.th Tanikan Viriyachinkarn is Lecturer at the Department of Accounting, Faculty of Business Administration, Chiang Mai University, Thailand. Email: tanikan.v@cmu.ac.th, tu_tanikan1@ hotmail.com
}

https://doi.org/10.22452/ajba.vol12no1.3 
after graduation, are key factors which enhance their accounting technical competence.

Theoretical contributions/Originality: This study contributes to the emergent interest in this field by focussing on how the ASEAN Economic Community (AEC) members like Thailand, responds to the needs of the IES. The ERG theory could be adapted in understanding the factors affecting the development of accounting technical competence, professional skills and professional values, ethics and attitudes.

Practitioner/Policy implications: The ERG theory assists managers in recognising that if growth opportunities are not furnished to employees, they may regress to relatedness needs. The findings thus suggest that in order to develop students' accounting technical skills (IES2), the academic institutions should encourage students to participate in accounting training programmes as a part of the course curriculum. The results further indicate that accounting professional skills (IES3) can be enhanced if they get acceptance from their superiors and co-workers.

Research limitations: The samples of this paper comprise accounting students from northern Thailand. Only three International Education Standards (IESs) which are implemented in Thailand are examined.

Keywords: Accounting Technical Competence, Professional Skills, Professional Values, Ethics and Attitudes

JEL Classification: M41, M48

\section{Introduction}

The accounting profession plays an important role in government development as well as private sector growth. The profession enables the country to achieve its financial performance, governance, transparency and to increase investor confidence. The accounting profession has emerged to be one of the eight professions in Thailand to face crucial competition, after Thailand joined the ASEAN Economic Community (AEC) in 2015. The establishment of the AEC has allowed professional accountants from a member country to be registered as an ASEAN Chartered Professional Accountant and to be able to practise in other member countries. The free flow of such skilled labour has accelerated the demand for such accountants to be equipped with a certain standard of quality and competency. These accountants need to be able to learn how things operate in different markets; they also need to know how to use new accounting tools and advanced IT systems, in order to be able 
to function effectively in a multicultural work environment (Alexia, 2014). In the case of Thailand, the economic integration requires that the country's accounting practices and professionals also undergo changes, so that they are aligned with international standards, including the International Education Standards (IESs) for Accounting Professions (Department of Trade Negotiations, 2011). The unequal accounting education standards and requirements between AEC members have highlighted the imperative need for these countries to develop their base of accounting professionals by enhancing their skills as recommended by the accounting international standards as proposed by the International Financial Reporting Standards (IFRS), and the International Education Standards for Professional Accountants (IES). By taking steps to enhance the professional accountants of the country, the competency of human capital in the accounting area would be insulated and perhaps even ameliorated. Without doubt, the establishment of the AEC has triggered several challenges for accounting professionals.

Many studies (Nguyen \& Gong, 2012; Steelyana, 2012; Suttipun, 2014) have examined the readiness of the accounting profession towards the AEC membership. They focussed on factors such as age, knowledge, capabilities and technical skills as factors which might propel the accounting profession to seek ways to prepare themselves for the impact of the AEC. While these studies focussed on the accounting profession's need for development in meeting the AEC movement, little attention has been given to the accounting education's harmonisation efforts with existing IESs. In Thailand, the Federation of Accounting Professions (FAP), under the Royal Patronage of His Majesty the King, has administered the IES for accounting practitioners since 2001 (Suttipun, Sattayarak, Duangpanya, \& Runglertkrengkrai, 2018). However, with unequal accounting education standards between AEC member countries and Thailand, it would seem that establishing IES requirements on the accounting profession in Thailand is the only means to ensure that the competency of its accounting professionals are insulated from other competitiveness. Therefore, the development and implementation of the IESs became a high-stake issue for all accounting professionals and academics (McPeak, Pincus, \& Sundem, 2012).

In view of the limited studies conducted within the IES framework, this study aims to examine factors affecting accounting professionals' essential skills that are within the IES framework. In a bid to understand more, this study employs Aldefer's (1969) theory of existence, relatedness and growth needs (ERG). The ERG theory was developed from 
Maslow's hierarchy of human basic needs for physiological, safety, love, esteem and self-actualisation (Maslow 1943). The theory developed by Alderfer (1969) is an alternative which refined Maslow's hierarchy of the five basic needs into three categories - existence, relatedness and growth. The first category - need for existence - is defined as the physical and material wants such as food, residence, salary, bonus, working environment and fair employment contract. The second category - relatedness need - is defined as the desire for interpersonal relationship with others/co-workers. The third category - growth need - is defined as the desire to be creative and productive such as for work promotions and new opportunities to develop and use one's talents. The ERG theory has been used as a construct to understand the internal drive that motivates human beings towards certain behaviours. With the establishment of the AEC in 2015, professional accountants are facing considerable challenges, which require them to enhance their competencies and skills, so that they can be more competitive and successful. While it is important for them to acquire skills that match the IES, the lack of intrinsic learning motivations may not lead to a positive outcome, despite encouraging work environments. Motivation refers to the unsatisfied needs that create a sense of tension and disequilibrium, causing the individuals to move towards a directed goal. Motivation is illustrated as the process of the individual's willingness to expand energy so as to attain an aim or reward. Thus, it is expected that internal motivations would influence the individual to acquire certain competencies, skills and values, with success. Thus, incorporating the ERG theory for the purpose of understanding the training needs of the accounting professionals may offer some insights and possibly, bridge the existing knowledge gaps. In the context of this study, we only focus on growth and relatedness needs because prior studies (Seger \& Graylee, 2013) have already found that existence needs, which involves salary and benefits, were less important and less significant.

This study is expected to contribute to current literature in the field of accounting education in several ways. First, the outcome contributes to the emergent interest in this field which focussed on how, as an AEC member, Thailand responded to the needs of the IES requirements. Thus, the findings will highlight on the steps needed to prepare Thai accounting students for intense global competition among ASEAN member countries. Second, the outcome generated can be contrasted with previous studies by examining how the ERG theory can be adapted for the purpose of understanding the different factors affecting the 
skill development of the accounting professionals in terms of technical competence, professional skills and professional values, ethics and attitudes. The implications to be drawn from this study indicate that the ERG theory assists the managers in recognising that an employee has multiple needs to satisfy, simultaneously. Therefore, growth opportunities should be provided to employees, otherwise, they would regress to their relatedness needs.

The remaining discussion of this paper is organised as follows. Section 2 reviews the literature pertaining to the ERG theory and the IES framework. Section 3 discusses the research model and hypotheses developed. Section 4 discusses the methodology employed, while Section 5 reports on the results. Section 6 discusses the findings and Section 7 concludes the paper by focusing on the implications for management and theory.

\section{Literature Review}

\subsection{International Education Standards}

The International Education Standard (IES) serves as the authority on matters relating to the accounting profession. It is used predominantly by the International Federation of Accountants (IFAC) member bodies when setting education requirements for professional accountants and aspiring professional accountants (International Accounting Education Standards Board, 2017). This paper emphasises on the IES 2 - Technical Competence, IES 3 - Professional Skills, and IES 4 Professional Values, Ethics and Attitudes. The reason is because these three standards have the most impact on the development of academic competencies and professional competencies for accounting students, upon their graduation. Linked to this is that IES 3 and IES 4 were implemented in the accounting education system of Thailand in 2017 (Federation of Accounting Professions, 2016). This paper could be one of the first to examine the determinants of IES 3 and IES 4 in the context of Thailand. Clearly, the objective of implementing these IES standards is to enhance the accounting professionals globally. By encouraging them to accelerate their competence in accounting, public trust is thus fortified (International Accounting Education Standards Board, 2017). As a consequence, the current study focusses on examining the factors that may assist stakeholders (educational institutions and business communities) in assisting the accounting professionals to ameliorate their learning and knowledge development. 
As the regulatory body, the International Education Standard (IES) prescribes the knowledge content for the professional accounting education programme. The IES also stresses the need for professional accountants to function as competent and ethical professionals. The notion of professional competence is understood as that which goes beyond the knowledge of principles, standards, concepts, facts and procedures. Professional competence is the integration and application of: (a) technical competence, (b) professional skills, and (c) professional values, ethics and attitudes (International Accounting Education Standards Board, 2017).

\subsubsection{Technical Competence (IES 2)}

The objective of IES 2 was meant to establish the technical competence of aspiring professional accountants so that they are able to perform their role as a professional accountant. Technical competence is the ability to apply professional knowledge to perform a task according to the defined standards, legislations and regulations which are relevant to professional accountants. Within IES 2, the content of the professional accounting education should consist of: 1) accounting, finance and related knowledge, 2) organisational and business knowledge, and 3) information technology knowledge and competencies (International Accounting Education Standards Board, 2014a).

\subsubsection{Professional Skills (IES 3)}

The objective of IES 3 was meant to establish an appropriate mix of skills which a professional accountant needs in order to function competently. The skills noted within IES 3 are categorised into four areas of competence (International Accounting Education Standards Board, 2014b). They include: 1) intellectual skills which relate to the accountant's ability to solve problems, to make decisions and to exercise professional judgement, 2) interpersonal and communication skills which relate to the accountant's ability to work and interact effectively with others, 3) personal skills which relate to the accountant's personal attitudes and behaviour, and 4) organisational skills which relate to the accountant's ability to perform effectively with or within an organisation, so as to obtain optimal results or outcomes from the people and the resources available. 


\subsubsection{Professional Values, Ethics, and Attitudes (IES 4)}

The objective of IES 4 was to prescribe the values, ethics and attitudes which a professional accountant needs to acquire during the education programme which leads to a qualification. Values, ethics and attitudes are defined as the behaviours and characteristics that would identify accountants as members of a profession. These include the ethical principles generally associated with accounting practices and are considered essential in defining the distinctive characteristics of professional accounting behaviour. Values, ethics and attitudes include the commitment to other elements such as: (a) technical competence and professional skills, (b) ethical behaviour (e.g. independence, objectivity, confidentiality and integrity), (c) professional etiquette (e.g. due care, timeliness, courteousness, respect, responsibility and reliability), (d) pursuit of excellence (e.g. commitment to continual improvement and lifelong learning), and (e) social responsibility (e.g. awareness and consideration of the public interest) (International Accounting Education Standards Board, 2014c: 7).

A review of the literature notes that papers written about the IES is relatively small as compared to the total publications conducted in the area of international accounting. Most of these articles tend to discuss the global implementation of the IES, from various regions to illustrate some international acceptance of the standards. Yet, there appears to be two opposing views relating to the IES establishment. On one hand, there are a handful of studies (Karreman, Ahern Jr, Kuijl, \& Marrian, 2007; Needles, 2008; Wilson et al., 2009) that suggest the use of IES as a potential benchmark to identify the strengths and weaknesses of professional accountants and auditors so that further development could be made. On the other hand, there are scholars (Stocks, 2009; Tweedie, Dyball, Hazelton, \& Wright, 2013) who suggest that the IES be utilised as a minimum requirement as an assurance of global consistency, instead of diminishing the differences.

From the geographical perspective, it was found that most studies were conducted in the context of developed economies, with Europe being the most dominant. Other regions, such as Asia appear to be less engaged with the discussion on the IES. In an early seminal work conducted by Needles (2005) and Quinn (2004), it was highlighted that the implementation of the IES in emerging countries, in comparison to the developed economies, may not be a smooth process, due to the lack of educational infrastructure and resources and the shortage of 
professionally qualified accountants who are willing to spend time mentoring junior level accountants. There are also empirical works (Crawford et al., 2010; Zeghal \& Mhedhbi, 2006) done to obtain evidence to show the extent of IES adoption in accounting education in universities across several countries. Based on a questionnaire survey, Crawford et al. (2010), for example, found an extant gap in universities' accounting programmes in relation to IES implementation, in a few countries. Zeghal and Mhedhbi (2006) analysed the factors affecting the adoption of IESs by developing countries. They found that countries with the highest literacy rates, capital markets and an Anglo-American culture, were more likely to adopt the IESs. Within the context of Thailand, to the best of the researchers' knowledge, there appears to be limited studies conducted on the IES framework. Most of the studies conducted seemed to concentrate on the readiness of local professional accountants towards the AEC in general. There were no specific references to any international standards. For example, Suttipun (2014), in an exploratory study, investigated the competencies of Thai accounting students and their readiness for the AEC. It was found that the accounting students' readiness for the AEC was at a medium high level.

The literature review conducted shows that there are different views on the IES. Some agree that IES influences the accounting education and training worldwide. Thus, the goal of the IES is to ensure that all stakeholders can rely on the competence of the professional accountants. It seems evident that studies looking at the IES movement are small and in particular, research on this area in the context of Thailand is lacking. Being a developing country, with a different economy and infrastructure, different results may be obtained from Thai samples. Therefore, it is imperative to conduct a study within the IES framework in Thailand.

\subsection{The Existence, Relatedness and Growth (ERG) Theory}

In this study, the ERG theory is used to examine how intrinsic motivations affect the acquisition of essential skills that are in line with the IES. As explained above, the ERG theory is unlike Maslow's theory. It does not entail a rigid step-like progression since it does not require one need to satisfy the lower need before progressing to a higherlevel need (Au, Ngai, \& Cheng, 2008). Thus, the ERG theory has been widely used in empirical studies (Wiley, 1997; Arnolds \& Boshoff, 2002; 
Yang, Hwang, \& Chen, 2011; Caulton, 2012). Evidence drawn from these studies show that it is related to human behaviours. Wiley (1997) used the ERG theory to observe motivational factors in the workplace. Data were collected from 550 employees working in industries such as retailing, services, manufacturing, insurance, utilities, health care and government agencies. It was found that the top five factors motivating employees were good wages, full appreciation for the work done, job security, growth in the organisation and interesting work. The same was noted in the study of Arnolds and Boshoff (2002) who investigated the influence of needs satisfaction on esteem and job performance. Focussing on top-level executives and frontline employees from a variety of industries in South Africa, they also found that top managers were motivated by growth needs; their performance intentions were influenced by their perception of opportunities for growth and advancement. In contrast, frontline employees were motivated by the need for growth. Yang et al. (2011) also used the ERG theory to investigate consumer satisfaction and desires when choosing mobile value-added services. They noted that, contrary to the predictions of the ERG theory, frustration with a service did not lead to a greater desire for services that address either the same need or lower order needs. Likewise, Islam and Ahmed (2014) conducted a comparative analysis between the US and Malaysian employees. They noted that lower basic need and existence, may not be an important criterion for the US subjects, as they were relatively better paid. In the context of training and development, Seger and Graylee (2013) found that salary and other personal benefits appeared to have insubstantial effect on employees' motivation to acquire new skills. They seemed more concerned with good image, and the ability of the training to bridge their knowledge, experiences and skills.

Based on these findings generated by past studies as indicated above, it can be deduced that the ERG theory is relevant for use in various contextual settings. The theory helps to highlight the internal factors driving human beings towards certain behaviours. A scrutiny of current literature, suggests that there is little research which use the ERG theory to examine the motives propelling aspiring accountants to acquire the necessary professional accounting skills. To the best of the researchers' knowledge, the current study serves as the first attempt to explain the determinants of the IES 2, IES 3 and IES 4 on accounting professional skills by applying the ERG theory. Based on the findings gathered from Seger and Graylee (2013), and Islam and Ahmed (2014), 
this study will thus focus on two different needs only - relatedness and growth. Considering that accountants earn a decent salary and benefits, it is deduced that the lower level needs may not be an attracting factor for the accounting subjects to aspire to acquire new skills.

\section{Research Model and Hypotheses Development}

Based on the literature, a conceptual model is developed. The model hypothesises that the internal needs of an individual, namely relatedness and growth, will influence his/her accounting technical competence, professional skills, values, ethics and attitudes. The following discusses the hypotheses development.

In the 21st century, organisations are putting more emphasis on salaries and other extrinsic rewards to satisfy the existence needs of employees. The effective system used by organisations to recognise and to reward individuals may motivate employees to acquire new essential skills since this may affect their entire being. However, despite the importance of a good salary and an effective reward system, some scholars (Albu, Nicolae Albu, \& Mădălina Girbina, 2012) have stressed that workplace diversity, as is prevalent in multicultural organisations, may also impact on employees' motivation since there is no one size fits all approach. In a study conducted by Albu et al. (2012), it was found that the stereotypes held of accountants from developed countries, were different, suggesting that the process of change and improvement, might also be different. Therefore, the motivation of certain accountants may be affected by the different country setting. Nonetheless, as professionals, it is expected that accountants would be inspired to acquire new skills that would add value to their professional attributes and not just due to immaterial rewards (Islam \& Ahmed, 2014). For example, enhancing their professional values, ethics and attitudes might enable the professional accountants to satisfy an intrinsic desire to do something good for society. Since accountants are well paid, the monetary incentives and rewards may not be a significant factor for them to acquire new skills. As such, they are expected to be more driven because the technical competence might offer them a sense of belonging and facilitate in bridging their knowledge and skills' gaps. They may be willing to acquire advanced professional accountancy knowledge, develop a continuing understanding of professional values, ethics and attitudes as well as equip themselves with the appropriate mix of professional skills so as to enable them to function as competent 
professional accountants within an increasingly complex and changing environment. Based on these arguments, this study postulates that:

$\mathrm{H}_{1}$ : Relatedness needs have a positive influence on professional accountants' growth needs.

Previous studies (Seger \& Grayler, 2013) on human capital have demonstrated that some employees associate their desire to acquire new skills with an expectation for career growth and future promotions. In the context of the accounting profession, it was reported that training programmes can enhance the personal development of professional accountants or increase their job opportunities (Suttipun, 2014). As accounting professionals are expected to operate on international scales, they are, nevertheless, regulated by national bodies. This creates the fundamental difference in how accounting is practised and regulated (Needles, 2005). As a result of this expectation, there is a willingness among the accounting professionals to acquire new and essential skills which are in line with international standards, as shown in Figure 1.

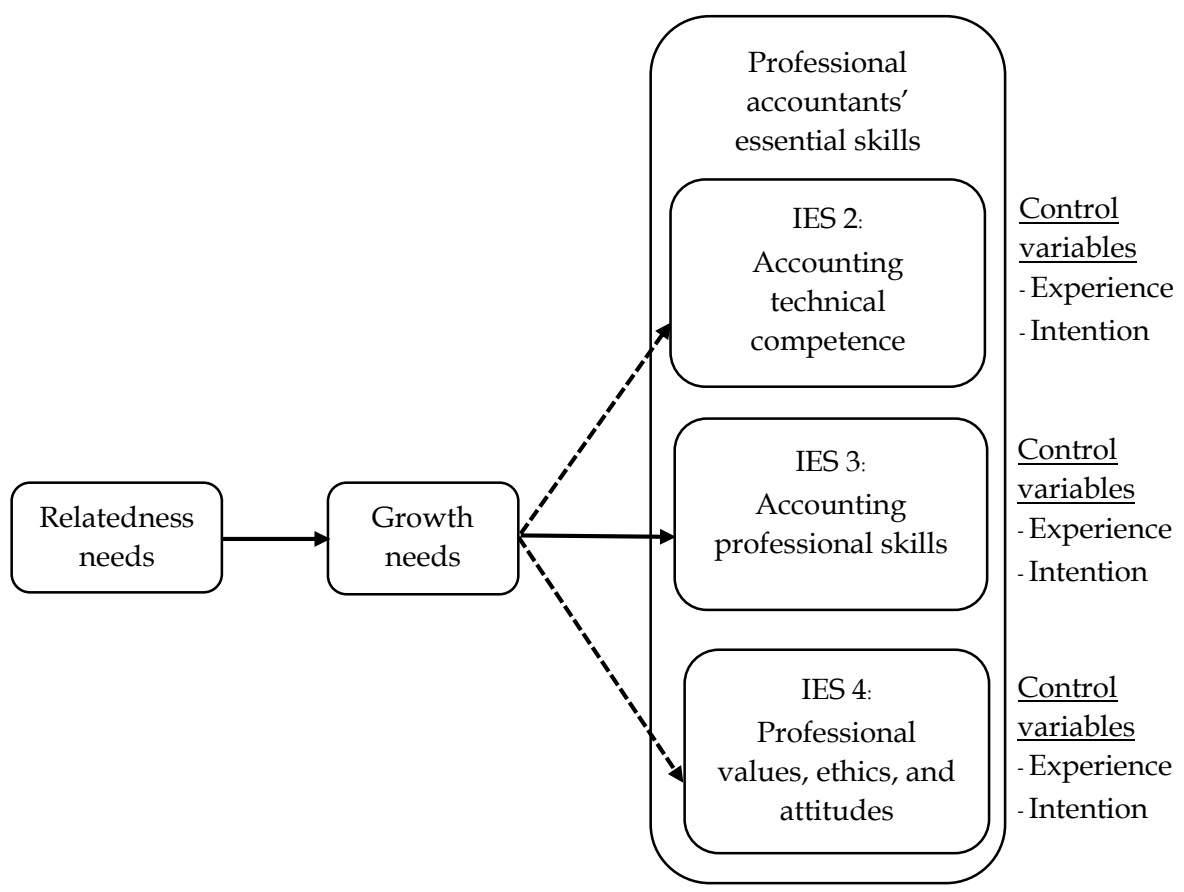

Figure 1: Conceptual Framework 
Doing so may offer them new opportunities to practise their professions in other countries. Based on these arguments, this study postulates that:

$\mathrm{H}_{2}$ : Growth needs have a positive influence on professional accountants' essential skills.

$\mathrm{H}_{2 \mathrm{a}}$ : Growth needs have a positive influence on accounting technical competence.

$\mathrm{H}_{2 \mathrm{~b}}$ : Growth needs have a positive influence on accounting professional skills.

$\mathrm{H}_{2 \mathrm{c}}$ : Growth needs have a positive influence on professional values, ethics and attitudes.

\section{Methodology}

\subsection{Sampling Methods and Respondents' Profiles}

As mentioned earlier, Thailand is chosen because IES 3 and IES 4 were recently implemented in the accounting education curriculum in Thailand (Federation of Accounting Professions, 2016). Apart from Bangkok, the capital city of Thailand, the northern part of Thailand has the highest number of universities per province, providing undergraduate and master's degree in accounting courses (Federation of Accounting Professions, 2018). The first regional university of Thailand was also established in the northern part of the country. Three types of university exist in Thailand: government, autonomous, and private. In the context of this study, data were collected from the largest universities of each type located in northern Thailand. The sampling frame consists of year 4 undergraduate accounting students who have internship experience in the accounting field. The lists of the students were obtained from the respective universities' administrators. Before the questionnaires were distributed for the actual study, ten respondents were selected for a pre-test. The feedback from the pretest in terms of consistency of wordings and redundant questions were addressed before the questionnaire was refined for distribution to a larger sample size. Students were used as samples in this study because the International Education Standards (IESs) were implemented in the accounting education curriculum for the purpose of developing their accounting skills. The International Education Standards (IESs) were implemented to enhance their professional competence so that they are equipped with the necessary domestic and international skills before 
they embark on the professional labour market. A total of 412, year four (4) students participated. Selection was based on random numbers noted in the list. Three universities - one government, one autonomous and one private were involved. The procedure was assisted by the head of the Accounting Department of the respective faculty/university. Of the 412 administered, only 204 completed questionnaires were retrieved, yielding a response rate of 49.5 per cent.

Table 1 presents the profiles. The demographic profile indicates that most were female students (88.24 per cent). Their ages ranged between 21 to 23 years old (96.08 per cent). All the respondents were fourth-year students, with 99.5 per cent of them having at least one-month's training experience in accounting, auditing, taxation or internal auditing.

Table 1: Demographic Profile of Respondents

\begin{tabular}{llrr}
\hline Demographic & \multicolumn{1}{c}{ Categories } & Numbers & Percentage \\
\hline Sex & Male & 24 & 11.76 \\
& Female & 180 & 88.24 \\
Age & Less than 18 years old & 1 & 0.49 \\
& 18 to 20 years old & 0 & 0.00 \\
& 21 to 23 years old & 196 & 96.08 \\
Training experience & More than 23 years old & 7 & 3.43 \\
& <1 month & 1 & 0.49 \\
& 1-3 months & 178 & 87.25 \\
& $>3$ months & 25 & 12.25 \\
\hline
\end{tabular}

\subsection{Operationalisation}

This study adapted measures from prior studies. However, since this study appears to be the first attempt to look into factors affecting the acquisition of accounting skills from the ERG perspective, an in-depth interview involving one auditor, one accounting technical specialist from the Federation of Accounting Professions, and three HODs (Head of Accounting Department) from three universities located in the north of Thailand was also conducted in the first stage of this study. The aim is to determine the appropriateness of the adapted scales, in the context of accounting skills. The outcome generated from the interview provided some insights into possible factors that may affect the 
undergraduate students' accounting technical competence, professional skills and professional values, ethics and attitudes. The interviews also confirmed that relatedness needs, and growth needs could serve as possible factors. More importantly, all the interviewees suggested that the measures for relatedness needs (which were adapted from previous studies and consisted of three items) were not relevant for the current study since it only involved accounting students as samples. According to the experts interviewed, some of the questions would not be able to capture the true meaning as they were related to a real working environment whereas the samples were accounting students. Therefore, this variable was measured by a single item. Measuring constructs with a single item is encouraged (Wanous, Reichers, \& Hudy, 1997; Rossiter, 2002) in the case of a narrow or unambiguous construct, such as this study is using. Hence, using a single-item measurement may suffice (Sackett \& Larson Jr, 1990). Moreover, this single-item measure has been validated with the expert panels. Face validity was established by showing all the scales to two accounting professionals and one academic scholar. All agreed that the items captured the meaning of each construct. The single item constructs have both face and content validity and are consistent with Rossiter's (2002) call for more parsimonious measures. Some additional factors resulting from the interviews were also added, such as training experience, expected income and expected future career. To provide a robustness test to our hypotheses and to add more academic and practical contributions, we included an experience variable (EXPER) and students' intention to work in the accounting arena after their graduation (INTENT) as control variables. The number of years that the students had experienced as a trainee in the accounting fields is a proxy for experience variable. Students' intention was measured by a 5-point Likert scale. These two control variables were derived from the in-depth interviews. All interviewees agreed that these two variables served as additional key factors propelling students to improve their accounting competence. In this regard, we expect that EXPER and INTENT will be positively related with their accounting technical competence, professional skills, and professional values, ethics and attitudes.

The above information was then used in combination with prior literature to develop items for the constructs contained in the questionnaire (Table 2). We pre-tested the final questionnaire with 10 students. To ensure that the scales used were valid and reliable, various validity and reliability tests were also performed. 
Table 2: Description of Scale Items

Dependent variables

1. Accounting technical competence (IES2)

IES2_1 Financial accounting and reporting

IES2_2 Management accounting

IES2_3 Finance and financial management

IES2_4 Taxation

IES2_5 Audit and assurance

IES2_6 Governance, risk management and internal control

IES2_7 Business laws and regulations

IES2_8 Information technology

IES2_9 Business and organisational environment

IES2_10 Economics

IES2_11 Business strategy and management

2. Professional skills (IES3)

IES3_1 Intellectual competence

IES3_2 Interpersonal and communication competence

IES3_3 Personal competence

IES3_4 Organisational competence

3. Professional values, ethics and attitudes (IES4)

IES4_1 Professional scepticism and professional judgment

IES4_2 Ethical principles

IES4_3 Commitment to the public interest

Independent variables

1. Relatedness needs (RELATE)

RELATE I want acceptance from my boss and co-workers for my future career.

2. Growth needs (GROW)

GROW_1 I seek a chance to apply my knowledge and my ability to improve my job performance in the future.

GROW_2 I am interested in working overseas.

GROW_3 I often think of a job that challenges my ability.

GROW_4 I intend to work at the company offering a clear-cut career path.

\subsection{Measurement Model Evaluation}

All the items in this study were subjected to scale purification, using confirmatory factor analysis (CFA). Convergent and discriminant validity were performed to ensure that the items used were in agreement and 
did not reflect other variables (Hair, Sarstedt, Hopkins, \& Kuppelwieser, 2014). In this study, convergent validity which denotes the degree of correlations between two or more measures of the same concept, was assessed by evaluating the factor loadings, composite reliability and average variance extracted values (Chin, 1998). As represented in Table 3 , most items were retained in this study, since their loadings were above 0.5 (Hulland, 1999). However, one item, IES2_11, was dropped

Table 3: Confirmatory Factor Analysis and Reliability of Constructs

\begin{tabular}{|c|c|c|c|c|}
\hline Variable & $\begin{array}{l}\text { Factor } \\
\text { Loading }\end{array}$ & $\begin{array}{c}\text { Composite } \\
\text { Reliability (CR) }\end{array}$ & $\begin{array}{c}\text { Average } \\
\text { Variance } \\
\text { Extracted (AVE) }\end{array}$ & $\begin{array}{c}\text { Cronbach's } \\
\text { alpha }\end{array}$ \\
\hline \multicolumn{2}{|c|}{ Accounting technical competence } & 0.943 & 0.609 & 0.879 \\
\hline IES2_1 & 0.555 & & & \\
\hline IES2_2 & 0.643 & & & \\
\hline IES2_3 & 0.585 & & & \\
\hline IES2_4 & 0.510 & & & \\
\hline IES2_5 & 0.661 & & & \\
\hline IES2_6 & 0.560 & & & \\
\hline IES2_7 & 0.694 & & & \\
\hline IES2_8 & 0.766 & & & \\
\hline IES2_9 & 0.672 & & & \\
\hline IES2_10 & 0.678 & & & \\
\hline IES2_11 & 0.341 & & & \\
\hline \multicolumn{2}{|c|}{ Professional skills } & 0.912 & 0.725 & 0.819 \\
\hline IES3_1 & 0.531 & & & \\
\hline IES3_2 & 0.708 & & & \\
\hline IES3_3 & 0.837 & & & \\
\hline IES3_4 & 0.697 & & & \\
\hline \multicolumn{2}{|c|}{ Professional values, ethics and attitudes } & 0.931 & 0.819 & 0.906 \\
\hline IES4_1 & 0.860 & & & \\
\hline IES4_2 & 0.882 & & & \\
\hline IES4_3 & 0.862 & & & \\
\hline \multicolumn{2}{|l|}{ Growth needs } & 0.868 & 0.625 & 0.772 \\
\hline GROW_1 & 0.610 & & & \\
\hline GROW_2 & 0.746 & & & \\
\hline GROW_3 & 0.735 & & & \\
\hline GROW_4 & 0.556 & & & \\
\hline
\end{tabular}

Note: Factor loadings greater than 0.50 are considered significant. 
from further analysis, as it loaded below the recommended value. The composite reliability values for all constructs were above 0.868 , thus it achieved the recommended value of 0.6 (Nunnally, 1978). Cronbach's alpha was also noted to be above the recommended 0.80 level (Bagozzi \& Yi, 1988; Bollen, 1989). Simultaneously, the Average Variance Extracted (AVE) values for all constructs were above 0.625. Therefore, these values were acceptable.

In this study, the discriminant validity test was performed in accordance to Fornell and Larcker's approach (1981). As shown in Table 4 , all the scales appeared to have a substantially higher AVE value with other constructs, when compared to their squared correlation. This demonstrates the achievement of the discriminant validity. Based on these results, it can be assumed that the measures used demonstrated adequate convergent and discriminant validity, hence further analysis can be conducted.

Table 4: Correlation Matrix

\begin{tabular}{lccccc}
\hline Construct & IES2 & IES3 & IES4 & RELATE & GROW \\
\hline IES2 & $\mathbf{( 0 . 7 8 0 )}$ & & & & \\
IES3 & $0.638^{* *}$ & $\mathbf{( 0 . 8 5 2 )}$ & & & \\
IES4 & $0.172^{*}$ & $0.503^{* *}$ & $\mathbf{( 0 . 9 0 5 )}$ & & \\
RELATE & 0.006 & 0.065 & 0.135 & $\mathbf{( 0 . 8 7 4 )}$ & \\
GROW & 0.089 & $0.199^{* *}$ & 0.120 & $0.267^{* *}$ & $\mathbf{( 0 . 7 9 0 )}$ \\
\hline
\end{tabular}

Notes: Figures in parentheses (boldfaced) indicate square root of AVE.

IES2 is Accounting technical competence, IES3 is Professional skills, IES4 is Professional values, ethics and attitudes. RELATE is Relatedness needs. GROW is Growth needs; ${ }^{* * *},{ }^{* *}, *$ indicate significant level at $1 \%, 5 \%$ and $10 \%$ respectively.

\section{Results}

\subsection{Empirical Results}

Assuming that the measurement model satisfied the validity and reliability issues, a structural model was then constructed, based on the results of the measurement model. The overall fit indices reported a $\chi^{2} /$ degree of freedom $(\mathrm{df})=1.814, \mathrm{p}$-value $=0.00$ level, the comparative fit index $(\mathrm{CFI})=0.902$, the root-mean square error of approximation $($ RMSEA $)=0.063$, and the incremental fit index $(\mathrm{IFI})=0.905$. All statistics 
indicated a reasonable model fit. The results are reported in Figure 2 and Table 5. Similar to the main model, Table 5 confirms that the satisfaction of relatedness needs has a significant $(\beta=0.150, p<0.10)$ impact on

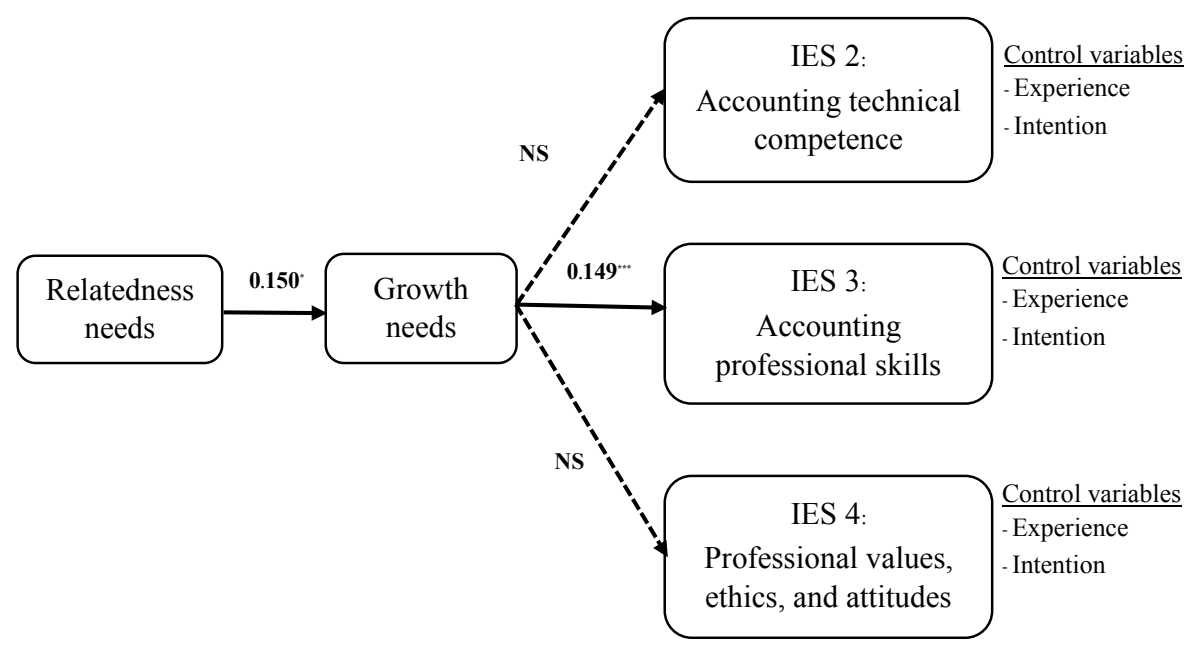

Figure 2: Structural Model Analysis

Note: NS denotes non-significant relationship. ***, * indicate significant level at $1 \%$ and $10 \%$ respectively.

Table 5: Regression Estimates

\begin{tabular}{lcccc}
\hline Paths & Hypotheses & Estimate & Standard Error & p-value \\
\hline RELATE $\rightarrow$ GROW & $\mathrm{H}_{1}$ & $0.150^{*}$ & 0.079 & 0.057 \\
GROW $\rightarrow$ IES2 & $\mathrm{H}_{2 \mathrm{a}}(+)$ & 0.069 & 0.044 & 0.118 \\
GROW $\rightarrow$ IES3 & $\mathrm{H}_{2 \mathrm{~b}}(+)$ & $0.150^{* * *}$ & 0.049 & 0.002 \\
GROW $\rightarrow$ IES4 & $\mathrm{H}_{2 \mathrm{c}}(+)$ & 0.127 & 0.103 & 0.218 \\
Control variables & & & & \\
EXPER $\rightarrow$ IES2 & & $0.170^{* * *}$ & 0.066 & 0.010 \\
EXPER $\rightarrow$ IES3 & & 0.008 & 0.065 & 0.899 \\
EXPER $\rightarrow$ IES4 & & 0.207 & 0.149 & 0.167 \\
INTENT $\rightarrow$ IES2 & & $0.050^{*}$ & 0.028 & 0.072 \\
INTENT $\rightarrow$ IES3 & & $0.117^{* * *}$ & 0.031 & 0.000 \\
INTENT $\rightarrow$ IES4 & & 0.071 & 0.066 & 0.282 \\
\hline
\end{tabular}

Note: IES2 is Accounting technical competence, IES3 is Professional skills, IES4 is Professional values, ethics and attitudes, RELATE is Relatedness needs, GROW is Growth needs, EXPER is experience and INTENT is intention. ***, * indicates significant level at $1 \%$ and $10 \%$ respectively. 
growth needs, hence supporting $\mathrm{H}_{1}$. This study also found that the impact of growth needs was only significant on accounting professional skills (IES3) $(\beta=0.149, \mathrm{p}<0.01)$, while the impact of growth needs on the other two skills - accounting technical competence and professional values, ethics and attitudes, was non-significant, thereby rejecting $\mathrm{H}_{2 \mathrm{a}}$ and $\mathrm{H}_{2 \mathrm{c}}$ while supporting $\mathrm{H}_{2 \mathrm{~b}}$. Based on this, it can be said that there is evidence to suggest that the student's needs for acceptance by their superiors and peers, drove their desire to challenge their abilities for future growth. The growth needs enhanced the students' accounting professional skills.

\section{Discussion}

Building on the ERG theory, this study has attempted to examine the factors that would likely affect the accounting professionals' essential skills as required by the IES framework, in the context of Thailand. Similar with previous studies (Islam \& Ahmed, 2014), this study found that relatedness needs stimulate accounting students desire to satisfy their growth needs. This is expected, as coming from a collectivist society, the psychological contract is relatively a strong drive for the students to equip themselves with appropriate professional skills, so that their career as an accountant is able to flourish in the future. As students, there is also a possibility that their perceptions about their future career growth lies in the centrality of the family. As indicated by Fuligni and Zhang (2004), students in a collectivist society commonly consider family obligation as a predictor of their academic motivation. A strong sense of obligation to the family, particularly parents, may serve as the motivational impetus for them to achieve better and to think about their future career. Hence, the accounting students of Thailand may recognise the legitimacy of their social surroundings, family as well as teachers, in making their educational decisions about their future career growth as professional accountants. These results also indicated that there is a higher chance for the respondents not to perform certain actions if those important persons do not agree with a particular future career growth decision. It is, therefore, possible to conclude that the accounting students of Thailand are likely to observe others' behaviours before they proceed with their own career decisions.

The findings of this study also highlight that fulfilment in one's personal career is the growth needs that the accounting students valued. Accounting students who perceived better self-efficacy in 
terms of how the acquired skills may make a difference in their future career, were more willing to develop their professional accounting skills. This is expected, considering that accounting students have a better academic background, and they anticipate a better grade. Hence, they were highly motivated by a challenging work environment and supportive instructors/supervisors. The satisfaction fulfilling this need gave the accounting students the opportunity to utilise their abilities and skills to their fullest potential. This finding suggests that providing opportunities for students to do challenging things at work will enhance their professional skills, including their intellectual skills, interpersonal and communication skills, personal skills and organisational skills. It appears that universities providing the accounting programmes need to offer the students relevant resources that will nurture their growth needs. This, in turn, will motivate them to acquire new skills as well as develop their skills further. At the practice level, the universities involved may need to increase the satisfaction of their growth needs by strengthening the link between the day-to-day classroom lectures with real life problems. The internship programme, for example, should not be treated as a mere training programme, but as an opportunity to contribute to the real business world by working on the real problems and issues, which their organisations experience. Such initiatives may create challenging roles and opportunities for the accounting students to not only learn and use their knowledge, but to also acquire new skills and knowledge for themselves, in envisioning a long-term career path in a globalised environment.

In comparing the effect of the growth needs with the three IES requirements, it was found that the effect is only significant for IES 3 - professional skills. This finding could be due to the fact that the accounting students were in their final year, and they have been furnished with quite an extensive level of accounting technical knowledge (Suttipun, 2014). Consequently, the accounting students saw the importance to develop and improve their accounting professional skills instead of the accounting technical skills. Similarly, being students, they may not see the importance of the ethical judgement and moral reasoning as a part of the accounting skills (Mustapha \& Siaw, 2012). This situation may lead to their inability to establish a link between growth needs and ethical values in this study. This result highlights that Thai universities have a duty to create awareness, and to integrate ethical issues into their accounting programmes. This is because the Thai accounting students need to understand the need to act ethically. 
This attribute would be reflected in their work after graduation, as it is also a part of the IES framework. Moreover, Thai universities should not concentrate solely on their students' skill and knowledge relating to accounting only but also to impart some ethical values for their accounting programmes.

\section{Academic and Managerial Implications}

This study provides a valuable contribution to academia and the business community. In terms of the academic contribution, this study is the first attempt to understand students' desires to improve their accounting competency, based on the EGR theory. The evidence presented in this paper affirmed that students' professional skills (IES 3) can be motivated by supporting the students' relatedness needs, and growth needs.

In terms of managerial implications, the findings indicated that in order to develop students' accounting technical skills (IES 2), the academic institutions should encourage them to participate in various accounting training programmes as a part of their course curriculum. The business units should also support training or internship programmes of institutions. This skill can enhance the students' excitement to be involved in the accounting field, upon graduation. The academic institutions should also provide a clear career path supported by a strong evidence of success cases of this profession as a further means to motivate students to work in the accounting field after graduation.

To enhance the image of the professional accountants, accounting firms or business owners should provide their accounting staff with a clear-cut career path and growth opportunity by emphasising the need to improve their professional skills (IES 3). These accounting staff can also be given opportunities to do more challenging tasks where they can use their knowledge and skills to improve their job performance. The results of this study also indicate that relatedness needs have a positive effect on growth needs. This implied that accounting professional skills (IES 3) can be enhanced when they get acceptance from their boss and co-workers. Such appreciations can make these professional accountants feel valued, hence they would engage with their work more. Consequently, they would be more enthusiastic and willing to deal with even a very difficult task. Therefore, the academic institutions may include communication and social skills as a part of the accounting curriculum where the tasks are designed in such a way as to encompass group work 
and where students are taught the effective techniques for giving and receiving feedback. Business units should also manage their accounting staff's communication and social skills as a means to ensure that such skills contribute to the growth needs of the professional accountants.

\section{Limitations and Future Research}

Although this paper offers many contributions to the stakeholders involved, there are some limitations too. First, the samples of this paper were confined to the accounting students from universities in northern Thailand. Future research can extend on the population by including accounting students from across the country in order to examine if the results would be similar. Second, this study only examined the effect of the ERG theory on three standards: IES 2, IES 3, and IES 4 . Future researchers may continue to study the factors that may affect the IES 1 to 8 , among graduate and undergraduate students. Finally, this paper applied Aldefer's (1969) ERG theory as the framework to examine human needs. Future research may consider other related human need theories such as Maslow's (1943) hierarchy of human basic needs, Macgregor's (1960) theory of X and Y, Herzberg's (1966) two factor theory, Vroom and Yetton's (1973) expectancy theory and Locke and Latham's (1990) goal setting theory.

\section{References}

Albu, N., Nicolae Albu, C., \& Mădălina Gîrbină, M. (2012). Educating accounting students in an emerging economy - An analysis of the importance of stereotypes in teaching IFRS. International Journal of Academic Research, 4(3), 51-57.

Alderfer, C.P. (1969). An empirical test of a new theory of human needs. Organizational Behavior and Human Performance, 4(2), 142-175. http:// dx.doi.org/10.1016/0030-5073(69)90004-X

Alexia, J. (2014). Implications of the AEC to the accounting industry (ACCA, Special Focus on AEC). Retrieved from https://www.pwc.com/my/en/assets/ press/141101-focus-msia-implications-of-the-aec-to-accounting-ind.pdf

Arnolds, C.A., \& Boshoff, C. (2002). Compensation, esteem valence and job performance: An empirical assessment of Alderfer's ERG theory. The International Journal of Human Resource Management, 13(4), 697-719. http:// dx.doi.org/10.1080/09585190210125868

$\mathrm{Au}$, N., Ngai, E.W.T., \& Cheng, T.C.E. (2008). Extending the understanding of end user information systems satisfaction formation: An equitable needs 
fulfillment model approach. MIS Quarterly, 32(1), 43-66. http://dx.doi. org $/ 10.2307 / 25148828$

Bagozzi, R.P., \& Yi, Y. (1988). On the evaluation of structural equation models. Journal of the Academy of Marketing Science, 16(1), 74-94. http://dx.doi. org/10.1007/BF02723327

Bollen, K.A. (1989). A new incremental fit index for general structural equation models. Sociological Methods \& Research, 17(3), 303-316. http://dx.doi. org/10.1177/0049124189017003004

CampusStar. (2016). List of universities in Thailand. Retrieved from http:// campus.campus-star.com/education/6592.html

Caulton, J.R. (2012). The development and use of the theory of ERG: A literature review. Emerging Leadership Journeys, 5(1), 2-8.

Chin, W.W. (1998). The partial least squares approach to structural equation modeling. In G.A. Marcoulides (Ed.), Methodology for business and management: Modern methods for business research (pp. 295-336). Mahwah, NJ: Lawrence Erlbaum Associates Publishers.

Crawford, L., Helliar, C., Monk, E., Mina, M., Teodori, C., Veneziani, M., ... \& Falgi, K. (2010). IES compliance and the knowledge, skills and values of IES 2, 3 and 4 (IAAER/ACCA Research Project). London: ACCA.

Department of Trade Negotiation. (2011). ASEAN economic community: AEC. Thailand: Ministry of Commerce.

Federation of Accounting Professions. (2016, October). Learning outcomes-based International Education Standards: Seminar to listen to the opinion. Bangkok: Author.

Federation of Accounting Professions. (2018). Institute courses that are certified by the Federation of Accounting Professions. Retrieved from http:// eservice.fap. or.th/edu/edu_degree_list.php

Fornell, C., \& Larcker, D.F. (1981). Evaluating structural equation models with unobservable variables and measurement error. Journal of Marketing Research, 18(1), 39-50. http://dx.doi.org/10.2307/3151312

Fuligni, A.J., \& Zhang, W. (2004). Attitudes toward family obligation among adolescents in contemporary urban and rural China. Child Development, 75(1), 180-192. http://dx.doi.org/10.1111/j.1467-8624.2004.00662.x

Hair, J.F., Sarstedt, M., Hopkins, L., \& Kuppelwieser, V.G. (2014). Partial least squares structural equation modeling (PLS-SEM): An emerging tool in business research. European Business Review, 26(2), 106-121.

Hulland, J. (1999). Use of partial least squares (PLS) in strategic management research: A review of four recent studies. Strategic Management Journal, 20(2), 195-204. http://dx.doi.org/10.1002/(SICI)1097-0266(199902)20:2<195::AID $-\mathrm{SMJ} 13>3.0 . \mathrm{CO} ; 2-7$

International Accounting Education Standards Board. (2014a). International Education Standard (IES) 2: Initial professional development - professional values, ethics and attitudes (Revised). New York: Author. 
International Accounting Education Standards Board. (2014b). International Education Standard (IES) 3: Initial professional development - professional values, ethics and attitudes (Revised). New York: Author.

International Accounting Education Standards Board. (2014c). International Education Standard (IES) 4: Initial professional development - professional values, ethics and attitudes (Revised). New York: Author.

International Accounting Education Standards Board. (2017). Handbook of international education pronouncements 2017. New York: Author.

Islam, R., \& Ahmed, S. (2014). Do managers and employees perceive motivating factors differently in Malaysia? International Journal of Business and Systems Research, 8(1), 72-90.

Karreman, G.H., Ahern Jr. J.T., Kuijl, J.G. and Marrian, I.F.Y. (2007). GAE 2007: Trends in global accounting education. Amsterdam: Royal NIVRA.

Locke, E.A., \& Latham, G.P. (1990). A theory of goal setting \& task performance. Englewood Cliffs, NJ: Prentice-Hall, Inc.

MacGregor, D. (1960). The human side of enterprise. New York, NY: McGraw-Hill.

Maslow, A.H. (1943). A theory of human motivation. Psychological Review, 50(4), 370-396. http://dx.doi.org/10.1037/h0054346

McPeak, D., Pincus, K.V., \& Sundem, G.L. (2012). The International Accounting Education Standards Board: Influencing global accounting education. Issues in Accounting Education, 27(3), 743-750. http://dx.doi.org/10.2308/ iace-50121

Mustapha, M., \& Siaw, L.S. (2012). Whistle blowing: Perceptions of future accountants. Paper presented at the International Conference on Economics Business Innovation. Singapore: IACSIT Press. Retrieved from http:// www.ipedr.com/vol38/028-ICEBI2012-A10029.pdf

Needles, B.E. (2005). Implementing international education standards: The global challenges. Accounting Education, 14(1), 123-129. http://dx.doi.org/ $10.1080 / 0963928042000332388$

Needles, B.E. (2008). International Education Standards (IES): Issues of implementation. A report on the third IAAER globalization roundtable. Accounting Education, 17(S1), 69-79. http://dx.doi.org/10.1080/0963928080 2095206

Nguyen, A.T., \& Gong, G. (2012). Vietnamese accounting reform and international convergence of Vietnamese accounting standards. International Journal of Business and Management, 7(10), 26-36.

Nunnally, J.C. (1978). Psychometric theory. New York, NY: McGraw-Hill.

Quinn, L.R. (2004). What's the state of international standards? We're still a long way from harmonization. Strategic Finance (April), 35-40.

Rossiter, J.R. (2002). The C-OAR-SE procedure for scale development in marketing. International Journal of Research in Marketing, 19(4), 305-335. http://dx.doi.org/10.1016/S0167-8116(02)00097-6

Sackett, P.R., \& Larson Jr., J.R., (1990). Research strategies and tactics in industrial and organizational psychology. In M.D. Dunnette \& L.M. 
Hough (Eds.), Handbook of industrial and organizational psychology (pp. 419489). Palo Alto, CA: Consulting Psychologists Press.

Seger, A., \& Graylee, A. (2013). Employee development programs: Employee motivation to attend voluntary technical trainings in High-tech companies in Sweden (Master thesis, University of Mälardalen, Denmark). Retrieved from http://www.diva-portal.org/smash/record.jsf?pid=diva2\%3A631754 \&dswid=-812

Steelyana, W. (2012, November). Preparing Indonesia skilled labor in the field of accounting, finance and capital market for ASEAN Economic Community 2015. Paper presented at the 1st International Conference on Business, International Relation and Diplomacy (ICOBIRD), Indonesia. Retrieved from http:/ / ssrn.com/abstract $=2193026$

Stocks, K.D. (2009). Comments Pertaining to Proposed Framework for International Education Standards for Professional Accountants, from Kevin D. Stocks, the President of Accounting Programs Leadership Group, American Accounting Association, Sarasota, FL. Retrieved from www.ifac.org/Guidance/EXDDetails.php?EDID $1 / 4120$

Suttipun, M. (2014). The readiness of Thai accounting students for the ASEAN Economic Community: An exploratory study. Asian Journal of Business and Accounting, 7(2), 139-157.

Suttipun, M., Sattayarak, O-A., Duangpanya, P., \& Runglertkrengkrai, S. (2018). Relationship between competency as per the international education standards for accounting professionals and the awareness and understanding of the Thai financial reporting standards for small and medium sized enterprises: A case study of accounting professionals in Thailand's southern region. Kasetsart Journal of Social Sciences, 39(3), 432-438. http:/ / dx.doi.org/10.1016/j.kjss.2018.06.013

Tweedie, D., Dyball, M.C., Hazelton, J., \& Wright, S. (2013). Teaching global ethical standards: A case and strategy for broadening the accounting ethics curriculum. Journal of Business Ethics, 115(1), 1-15. http://doi. org/10.1007/s10551-012-1364-9

Vroom, V., \& Yetton, P. (1973). Leadership and decision-making. Pittsburgh, PA: University of Pittsburgh Press. http://dx.doi.org/10.2307/j.ctt6wrc8r

Wanous, J.P., Reichers, A.E., \& Hudy, M.J. (1997). Overall job satisfaction: How good are single-item measures? Journal of Applied Psychology, 82(2), 247252. http://dx.doi.org/10.1037/0021-9010.82.2.247

Wiley, C. (1997). What motivates employees according to over 40 years of motivation surveys? International Journal of Manpower, 18(3), 263-280. http:/ / dx.doi.org/10.1108/01437729710169373

Wilson, R.M., Pierce, A., Allison, M., Hoogendoorn, M., Kral, B., \& Watty, K. (2009). Accountancy and academic/professional inter-dependency (or mutual exclusivity?). Accounting in Europe, 6(2), 149-166. http://dx.doi. org/10.1080/17449480903171962 
Yang, C-L., Hwang, M., \& Chen, Y-C. (2011). An empirical study of the existence, relatedness and growth (ERG) theory in consumer's selection of mobile value-added services. African Journal of Business Management, 5(19), 7885-7898. http://dx.doi.org/10.5897/AJBM10.1586

Zeghal, D., \& Mhedhbi, K. (2006). An analysis of the factors affecting the adoption of international accounting standards by developing countries. The International Journal of Accounting, 41(4), 373-386. http://dx.doi.org/ 10.1016/j.intacc.2006.09.009 